\title{
Plasma Malondialdehid and Histopatology Healing Score Differences in Incised Old and Young Mice with Zinc Administration
}

\author{
Moniq W Aryantie, Rizqy D Monica, Andri Rezano, Sudigdo Adi, \\ Kiki A Rizki, Yenni Zuhairini
}

Biomedical Sciences Master Program, Faculty of Medicine, Universitas Padjadjaran Jl. Prof. Eyckman 38, Bandung 40161, West Java, Indonesia

Email: monicarizqydimas@yahoo.com

\begin{abstract}
Free radical plays role in wound healing. This study was conducted to determine differences in level of plasma malondialdehyde (MDA), and histopathological score of wound healing by administering zinc in old and young mice. We used 24 old mice and 24 young mice incision wound model, randomized into two groups, with and without zinc administration. We found plasma MDA level was lower in old mice with zinc administration but not statistically significant. The plasma MDA level was significantly higher by administering zinc in young mice $(p=0.004)$. The plasma MDA level of young mice was higher than old mice in zinc administration group $(p=0.010)$. Reepitelialization, inflammatory cells, fibroblasts and angiogenesis did not differ by administering zinc both in old mice and young mice. Reepitelialization, inflammatory cells and angiogenesis did not differ between old and young mice in mice that were given zinc; while fibroblast of young mice is more than old mice ( $p=0.010)$. We concluded plasma MDA level is higher in young mice with zinc administration. Plasma MDA level in young mice is higher than old mice with zinc administration. Young mice with zinc administration have higher fibroblast than old mice.
\end{abstract}

Keywords: aging, free radical, histopathologic score, malondialdehid, wound healing, zinc 


\title{
Perbedaan Kadar Malondialdehid Plasma dan Skor Histopatologi Penyembuhan Luka Insisi dengan Pemberian Seng pada Mencit Tua dan Muda
}

\author{
Moniq W Aryantie, Rizqy D Monica, Andri Rezano, Sudigdo Adi, \\ Kiki A Rizki, Yenni Zuhairini \\ Program Studi Magister Ilmu Kedokteran Dasar, \\ Fakultas Kedokteran, Universitas Padjadjaran \\ Jl. Prof Eyckman 38 Bandung 40161, Jawa Barat, Indonesia \\ Email: monicarizqydimas@yahoo.com
}

\begin{abstract}
Abstrak
Radikal bebas berperan dalam penyembuhan luka. Penelitian ini dilakukan untuk mengetahui perbedaan kadar malondialdehid (MDA) plasma dan skor histopatologi penyembuhan luka dengan pemberian seng pada mencit tua dan muda. Studi eksperimental ini menggunakan mencit tua dan muda model luka insisi masing-masing 24 ekor. Objek dirandomisasi menjadi dengan seng dan tanpa pemberian seng. Kami menemukan bahwa kadar MDA plasma lebih rendah dengan pemberian seng pada mencit tua, namun tidak bermakna. Kadar MDA plasma lebih tinggi dengan pemberian seng pada mencit muda $(p=0,004)$. Kadar MDA plasma mencit muda lebih tinggi dibandingkan dengan mencit tua pada mencit yang diberi seng $(p=0,010)$. Reepitelialisasi, sel inflamasi, fibroblas dan angiogenesis tidak berbeda dengan pemberian seng, baik pada mencit tua maupun mencit muda. Reepitelialisasi, sel inflamasi dan angiogenesis tidak berbeda antara mencit tua dan muda pada mencit yang diberi seng; sementara fibroblas mencit muda lebih banyak dibandingkan dengan mencit tua $(p=0,010)$. Penelitian ini menyimpulkan kadar MDA plasma lebih tinggi dengan pemberian seng pada mencit muda. Kadar MDA plasma mencit muda lebih tinggi dibandingkan dengan mencit tua pada mencit yang diberi seng. Fibroblas mencit muda lebih banyak dibandingkan dengan mencit tua pada mencit yang diberi seng.
\end{abstract}

Kata kunci: penuaan, penyembuhan luka, skor histopatologis, radikal bebas, seng 


\section{Pendahuluan}

Luka merupakan masalah kesehatan yang cukup sering terjadi, misalnya pada tahun 2009 ditemukan sekitar 180 juta kasus luka di dunia. Jenis luka yang paling banyak adalah luka sayat/insisi akibat pembedahan (110 juta kasus) dan luka robek/laserasi (20,4 juta kasus); diikuti dengan ulkus diabetes (13,5 juta kasus), ulkus vena (12,5 juta kasus), dan ulkus dekubitus $(8,5$ juta kasus). ${ }^{1}$ Risiko luka akibat jatuh lebih besar pada lanjut usia (lansia) karena adanya penurunan kekuatan tulang dan sendi, kehilangan massa otot dan kulit, serta seringnya keluhan pusing. ${ }^{2}$

Luka pada lansia sering mengalami komplikasi berupa nyeri, infeksi, dan ulkus/gangren; sehingga menimbulkan dampak sosial dan ekonomi bagi penderita serta meningkatkan kesulitan dalam perawatan. Pelayanan kesehatan untuk pengobatan luka akut, luka kronik, dan penyembuhan luka terlambat pada lansia di Inggris menghabiskan biaya lebih dari 1 milyar poundsterling per tahun. ${ }^{3}$

Penyembuhan luka merupakan suatu proses yang dapat diprediksi namun tumpang tindih; terdiri dari respon hemostasis dan fase inflamasi, fase proliferasi, serta fase remodeling dan maturasi. ${ }^{4}$ Tiap fase memerlukan mediator cair (sitokin, kemokin, dan growth factor), sel (sel darah, sel yang berperanan dalam inflamasi, dan sel parenkim), serta matriks ekstraseluler. Luka sembuh secara normal dalam waktu 6-8 minggu setelah cedera. ${ }^{5}$

Perlukaan dapat menyebabkan penurunan antioksidan dan meningkatkan kebutuhan nutrisi dan menambah defisiensi akibat status malnutrisi sebelumnya. ${ }^{6}$ Intervensi untuk penyembuhan luka dapat dilakukan antara lain dengan pemberian antiinflamasi dan antioksidan, serta nutrisi untuk membantu proliferasi luka. ${ }^{7}$ Seng merupakan mikromineral yang memenuhi ketiga fungsi tersebut. Seng mudah didapatkan dengan harga yang murah, dan bentuk seng per oral mudah diberikan dengan dicampurkan ke dalam makanan atau dilarutkan ke dalam minuman. ${ }^{8}$

Seng merupakan regulator dan struktur antioksidan, yaitu enzim superoxide dismutase (SOD) yang berguna untuk membuang radikal superoksida selama debridement luka dan metallothionein yang menyediakan seng bebas pada kondisi stres oksidatif. ${ }^{9}$ Sebagai antiinflamasi, seng secara tidak langsung menghambat pembentukan sitokin proinflamasi. Seng juga merupakan koenzim berbagai macam enzim yang esensial dalam penyembuhan luka. Seng melalui enzim deoxyribonucleic acid (DNA) polimerase dan ribonucleic acid (RNA) polimerase; dibantu oleh hormon insulin-like growth factor-1 (IGF-1) meningkatkan proliferasi sel, sintesis protein dan kolagen, serta re-epitelisasi. Seng melalui matrix metalloproteinase 
(MMP) melakukan autodebridemen dalam remodeling luka, serta migrasi fibroblas dan sel epitel. ${ }^{10}$

Penyembuhan luka yang normal mengikuti pola terprediksi, namun tumpang tindih dalam waktu. Berdasarkan populasi sel dan aktifitas biologi, penyembuhan luka dapat dibedakan menjadi tiga fase, yaitu: 1) hemostasis dan fase inflamasi, 2) fase proliferasi, serta 3) fase remodeling dan maturasi. ${ }^{11}$ Penelitian ini akan mengetahui perbedaan kadar MDA plasma dan skor histopatologi penyembuhan luka dengan pemberian seng pada mencit tua dan muda dengan luka insisi. ${ }^{12}$

Malondialdehid merupakan salah satu produk peroksidasi lipid oleh ROS yang dapat dideteksi dengan mudah di plasma darah. ${ }^{13}$ Malondialdehid dalam penelitian ini merupakan indikator adanya peroksidasi lipid atau stres oksidatif akibat proses inflamasi pada luka kulit. Berbagai penelitian menunjukkan peran seng terhadap penyembuhan luka pada usia muda. Namun, penelitian mengenai peran seng terhadap penyembuhan luka pada usia tua belum banyak dilakukan. Penelitian ini bertujuan untuk mengetahui perbedaan kadar malondialdehid (MDA) plasma dan skor histopatologi penyembuhan luka dengan pemberian seng pada mencit tua dan muda dengan luka insisi.

Penyembuhan luka yang normal mengikuti pola terprediksi, namun tumpang tindih dalam waktu. Berdasarkan populasi sel dan aktifitas biologi, penyembuhan luka dapat dibedakan menjadi tiga fase, yaitu: 1) hemostasis dan fase inflamasi, 2) fase proliferasi, serta 3) fase remodeling dan maturasi.12 Penelitian ini akan mengetahui perbedaan kadar MDA plasma dan skor histopatologi penyembuhan luka dengan pemberian seng pada mencit tua dan muda dengan luka insisi. ${ }^{12}$

\section{Metode}

Penelitian ini merupakan penelitian eksperimental laboratorik rancang acak lengkap (RAL) dengan perlakuan pemberian seng. Penelitian menggunakan mencit sebagai objek penelitian dengan model luka insisi. ${ }^{14}$ Objek penelitian adalah mencit (Mus musculus) jantan galur Swiss Webster. Mencit diperoleh dari Pusat Ilmu Hayati (PIH) Institut Teknologi Bandung (ITB). Pada penelitian ini digunakan mencit karena struktur kulitnya mirip dengan kulit manusia, begitu juga organ-organ dalamnya. Pemilihan jenis kelamin jantan bertujuan untuk menghindari adanya pengaruh hormonal yang dapat mempengaruhi respon reaksi imunologis. Mencit muda yang digunakan adalah mencit usia 8 minggu dengan berat badan 2535 gram, sedangkan mencit tua adalah mencit usia 35 minggu dengan berat badan 40-50 gram. 
Mencit dieksklusi jika terdapat penurunan berat badan selama masa adaptasi $>10 \%$, terlihat sakit, atau mengalami komplikasi infeksi pada luka.

Sampel penelitian dibagi menjadi 4 kelompok perlakuan secara acak, yaitu: mencit tua dengan luka insisi yang diberi seng, mencit tua dengan luka insisi yang tidak diberi seng, mencit muda dengan luka insisi yang diberi seng, dan mencit muda dengan luka insisi yang tidak diberi seng.

Pada mencit kemudian dilakukan insisi di daerah punggung setelah dibius dengan menggunakan ketamin secara intramuskular. Dosis seng yang diberikan adalah 0,156 mg seng/hari/ekor untuk mencit muda dan $0,234 \mathrm{mg}$ seng/hari/ekor untuk mencit tua, berbeda karena disesuaikan dengan konversi dengan berat badan mencit. Setiap dosis pemberian dilarutkan dalam aquabides dengan konsentrasi $0,25 \mathrm{mg} / \mathrm{ml}$. Larutan seng diberikan per sonde ke lambung mencit untuk kelompok perlakuan setiap pagi. ${ }^{15}$

Kadar malondialdehid (MDA) dalam darah mencit dinilai dengan menggunakan metode TBARS (thiobarbituric acid reactive substances dan dilakukan pada hari ke-5. Pemeriksaan hostopatologi dilakukan pada hari ke-10, yaitu pada fase akhir penyembuhan luka. Parameter yang dinilai adalah reepitelialisasi, sel inflamasi, fibroblas dan angiogenesis.

\section{Tabel 1 Skor histopatologi pada penyembuhan luka kulit}

\begin{tabular}{|c|c|c|c|c|}
\hline Skor & Reepitelialisasi & Sel Inflamasi & Fibroblas & Angiogenesis \\
\hline 0 & Ketebalan tepi luka & Tidak ada & Tidak ada & Tidak ada \\
\hline 1 & $\begin{array}{l}\text { Migrasi sel pada < } \\
50 \% \text { permukaan } \\
\text { luka }\end{array}$ & $\begin{array}{l}\text { Sedikit di jaringan } \\
\text { sekitarnya }\end{array}$ & $\begin{array}{c}\text { Sedikit di jaringan } \\
\text { sekitarnya }\end{array}$ & $\begin{array}{l}\text { Sedikit di jaringan } \\
\text { sub kutan }\end{array}$ \\
\hline 2 & $\begin{array}{c}\text { Migrasi sel pada } \geq \\
50 \% \text { permukaan } \\
\text { luka }\end{array}$ & $\begin{array}{c}\text { Sedikit di garis } \\
\text { perbatasan/jaringan } \\
\text { granulasi }\end{array}$ & $\begin{array}{c}\text { Sedikit di jaringan } \\
\text { granulasi }\end{array}$ & $\begin{array}{c}\text { Sedikit di jaringan } \\
\text { granulasi }\end{array}$ \\
\hline 3 & $\begin{array}{l}\text { Menjembatani } \\
\text { irisan luka }\end{array}$ & $\begin{array}{c}\text { Sedang di garis } \\
\text { perbatasan/jaringan } \\
\text { granulasi }\end{array}$ & $\begin{array}{l}\text { Sedang di } \\
\text { jaringan granulasi }\end{array}$ & $\begin{array}{l}\text { Sedang di } \\
\text { jaringan granulasi }\end{array}$ \\
\hline 4 & Keratinisasi & $\begin{array}{c}\text { Banyak di garis } \\
\text { perbatasan/jaringan } \\
\text { granulasi }\end{array}$ & $\begin{array}{c}\text { Banyak di } \\
\text { jaringan granulasi }\end{array}$ & $\begin{array}{c}\text { Banyak di } \\
\text { jaringan granulasi }\end{array}$ \\
\hline
\end{tabular}

\section{Hasil}

Pada hari ke-5 ditemukan 2 ekor mencit tua yang tidak diberi seng mati, di akhir percobaan ditemukan lagi 2 ekor mencit tua yang diberi seng dan 3 ekor mencit tua yang tidak diberi seng mati, sehingga data dari mencit-mencit ini tidak diikutsertakan dalam penilaian. 
Malondialdehid dalam penelitian ini merupakan indikator adanya peroksidasi lipid atau stres oksidatif akibat proses inflamasi pada luka kulit. Sebelum menganalisis hasil kadar MDA plasma, terlebih dahulu dilakukan uji normalitas dengan uji Shapiro-Wilk, masing-masing pada mencit tua dan muda. Data berdistribusi normal baik pada mencit tua maupun mencit muda. Lalu dilakukan uji parametrik untuk menguji hipotesis, yaitu uji $\mathrm{T}$ tidak berpasangan.

Hasil penelitian pada mencit tua dengan luka insisi didapatkan kadar MDA plasma lebih rendah dengan pemberian seng, namun secara statistik tidak bermakna $(p=0,064)$. Perbedaan kadar MDA plasma dengan pemberian seng pada mencit tua dengan luka insisi tercantum pada tabel 2.

Tabel 2 Perbedaan kadar MDA plasma dengan pemberian seng pada mencit tua dengan luka insisi

\begin{tabular}{|c|c|c|c|c|c|c|}
\hline \multirow[b]{2}{*}{ Variabel } & \multicolumn{2}{|c|}{ Mean } & \multicolumn{2}{|c|}{ Standar deviasi } & \multirow[b]{2}{*}{$\mathbf{T}$} & \multirow[b]{2}{*}{$\begin{array}{c}\text { Nilai } \\
p\end{array}$} \\
\hline & $\begin{array}{c}\text { Mencit tua } \\
\text { seng }(+)\end{array}$ & $\begin{array}{c}\text { Mencit tua } \\
\text { seng (-) }\end{array}$ & $\begin{array}{c}\text { Mencit tua } \\
\text { seng (+) }\end{array}$ & $\begin{array}{c}\text { Mencit tua } \\
\text { seng (-) }\end{array}$ & & \\
\hline Kadar MDA plasma & 8,9 & 12,6 & 1,274 & 4,119 & 2,150 & 0,064 \\
\hline
\end{tabular}

Keterangan:

- Uji T tidak berpasangan, bermakna pada taraf alpha 5\% (nilai $p<0,05$ )

- $\mathrm{n}=6$ ekor pada kelompok perlakuan, $\mathrm{n}=4$ ekor pada kelompok kontrol

Dari hasil penelitian pada mencit muda dengan luka insisi didapatkan kadar MDA plasma lebih tinggi secara bermakna dengan pemberian seng $(p=0,004)$. Perbedaan kadar MDA plasma dengan pemberian seng pada mencit muda dengan luka insisi tercantum pada tabel 3 .

Tabel 3 Perbedaan kadar MDA plasma dengan pemberian seng pada mencit muda dengan luka insisi

\begin{tabular}{|c|c|c|c|c|c|c|}
\hline \multirow[b]{2}{*}{ Variabel } & \multicolumn{2}{|c|}{ Mean } & \multicolumn{2}{|c|}{ Standar deviasi } & \multirow[b]{2}{*}{$\mathbf{T}$} & \multirow[b]{2}{*}{$\begin{array}{c}\text { Nilai } \\
\boldsymbol{p}\end{array}$} \\
\hline & $\begin{array}{c}\text { Mencit muda } \\
\text { seng (+) }\end{array}$ & $\begin{array}{l}\text { Mencit muda } \\
\text { seng (-) }\end{array}$ & $\begin{array}{c}\text { Mencit muda } \\
\text { Seng (+) }\end{array}$ & $\begin{array}{c}\text { Mencit muda } \\
\text { seng (-) }\end{array}$ & & \\
\hline $\begin{array}{l}\text { Kadar MDA } \\
\text { plasma }\end{array}$ & 14,3 & 6,6 & 4,936 & 1,527 & $-3,674$ & 0,004 \\
\hline
\end{tabular}

Keterangan:

- Uji T tidak berpasangan, bermakna pada taraf alpha 5\% (nilai $p<0,05$ )

- $\mathrm{n}=6$ ekor/kelompok

Hasil penelitian pada mencit dengan luka insisi yang diberi seng didapatkan kadar MDA plasma mencit muda lebih tinggi secara bermakna dibandingkan dengan mencit tua $(p=0,010)$. Perbedaan kadar MDA plasma antara mencit tua dan muda pada mencit dengan luka insisi yang diberi seng tercantum pada tabel 4. 
Tabel 4 Perbedaan kadar MDA plasma antara mencit tua dan muda pada mencit dengan luka insisi yang diberi seng

\begin{tabular}{|c|c|c|c|c|c|c|}
\hline \multirow[b]{2}{*}{ Variabel } & \multicolumn{2}{|c|}{ Mean } & \multicolumn{2}{|c|}{ Standar deviasi } & \multirow[b]{2}{*}{$\mathbf{T}$} & \multirow[b]{2}{*}{$\begin{array}{c}\text { Nilai } \\
p\end{array}$} \\
\hline & $\begin{array}{c}\text { Mencit tua } \\
\text { seng (+) }\end{array}$ & $\begin{array}{l}\text { Mencit muda } \\
\text { seng (+) }\end{array}$ & $\begin{array}{c}\text { Mencit tua } \\
\text { seng }(+)\end{array}$ & $\begin{array}{l}\text { Mencit muda } \\
\text { seng }(+)\end{array}$ & & \\
\hline $\begin{array}{l}\text { Kadar MDA } \\
\text { Plasma }\end{array}$ & 8,9 & 14,3 & 1,274 & 4,936 & 3,142 & 0,010 \\
\hline
\end{tabular}

Keterangan:

- Uji T tidak berpasangan, bermakna pada taraf alpha 5\% (nilai $p<0,05$ )

- $\mathrm{n}=6$ ekor/kelompok

Pada hasil skor histopatologi penyembuhan luka, syarat untuk uji Chi-Square tidak terpenuhi maka dilakukan uji alternatifnya yaitu uji Fisher. Perbedaan skor histopatologi penyembuhan luka dapat dilihat pada gambar 1 sampai dengan 4 .

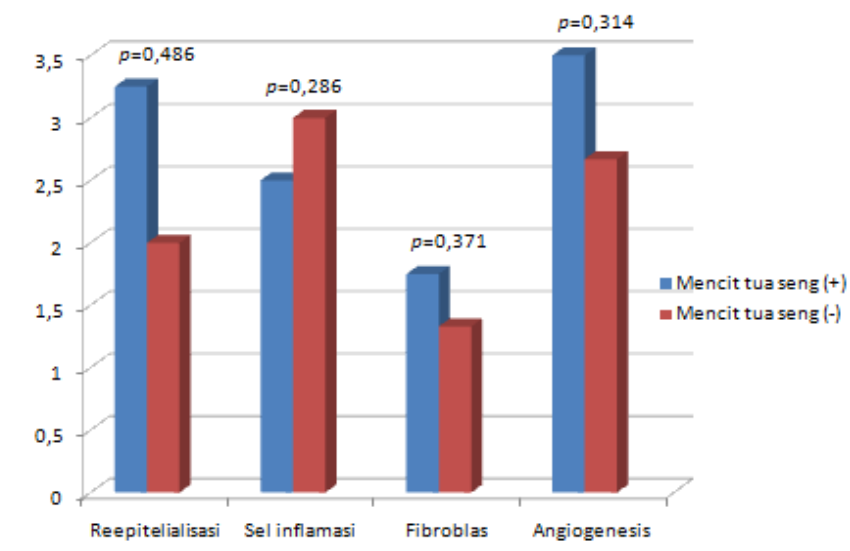

\section{Gambar 1 Perbedaan skor histopatologi penyembuhan luka dengan pemberian seng pada mencit tua dengan luka insisi.}

Gambar 1 menunjukkan rerata skor histopatologi penyembuhan luka kelompok yang diberi seng dan yang tidak diberi seng pada mencit tua dengan luka insisi. Hasil penelitian pada mencit tua dengan luka insisi didapatkan reepitelialisasi, fibroblas dan angiogenesis lebih banyak serta sel inflamasi lebih sedikit dengan pemberian seng. Namun perbedaan ini secara statistik tidak bermakna $(p>0,05)$.

Gambar 2 menunjukkan rerata skor histopatologi penyembuhan luka kelompok yang diberi seng dan yang tidak diberi seng pada mencit muda dengan luka insisi. Hasil penelitian pada mencit muda dengan luka insisi didapatkan reepitelialisasi, fibroblas dan angiogenesis lebih banyak serta sel inflamasi lebih sedikit dengan pemberian seng. 
Research Article

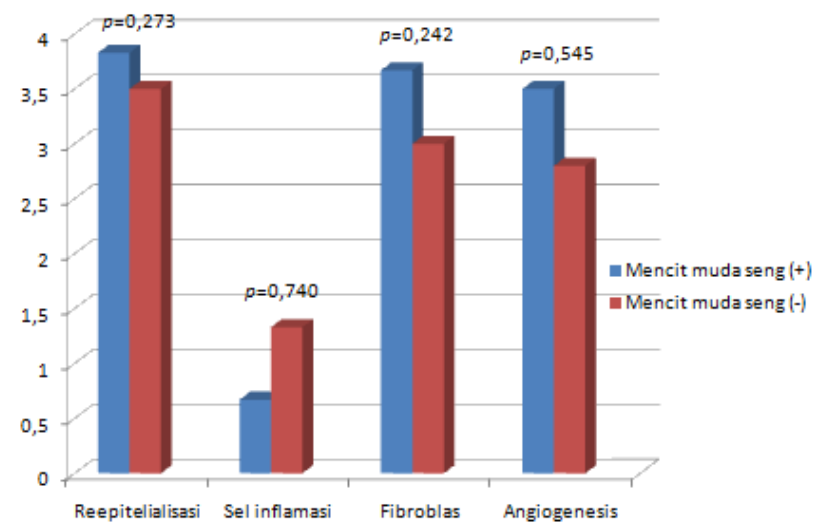

\section{Gambar 2 Perbedaan skor histopatologi penyembuhan luka dengan pemberian seng pada mencit muda dengan luka insisi}

Gambar 3 menunjukkan rerata skor histopatologi penyembuhan luka mencit tua dan muda pada mencit dengan luka insisi yang diberi seng. Hasil penelitian pada mencit dengan luka insisi yang diberi seng didapatkan reepitelialisasi, angiogenesis dan sel inflamasi tidak berbeda antara mencit tua dan muda $(p>0,05)$; sementara fibroblas mencit muda lebih banyak dibandingkan dengan mencit tua $(p=0,010)$.

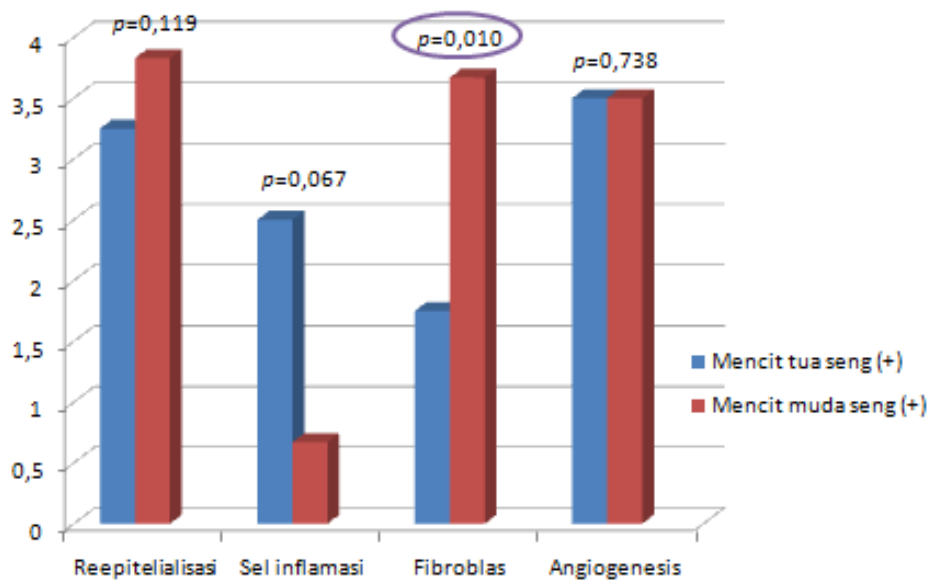

Gambar 3 Perbedaan skor histopatologi penyembuhan luka antara mencit tua dan muda pada mencit dengan luka insisi yang diberi seng

\section{Diskusi}

Perlukaan adalah kondisi yang dapat meningkatkan radikal bebas, menurunkan antioksidan, meningkatkan kebutuhan nutrisi dan menambah defisiensi yang telah terjadi sebelumnya. Binnebosel M dkk (2010) menemukan bahwa defisiensi seng secara nyata 
meningkatkan aktivitas MMP, menurunkan rasio kolagen tipe I/III, memperlambat proliferasi, dan mengurangi kualitas penyembuhan luka usus. ${ }^{17}$

Pemberian seng diharapkan dapat mengatasi defisiensi seng yang mungkin terjadi, menurunkan radikal bebas dan inflamasi, serta memperbaiki penyembuhan luka pada penuaan. Kebutuhan seng paling tinggi adalah sejak perlukaan hingga fase inflamasi dini. Kaplan B dkk (2004) melakukan penelitian menggunakan kelinci dengan luka insisi full-thickness dan menemukan bahwa pemberian seng sebaiknya diberikan hanya pada periode luka awal. Pada penelitian ini seng diberikan secara oral dengan sonde melalui mulut ke lambung mencit dengan dosis $0,156 \mathrm{mg}$ seng/hari/ekor untuk mencit muda dan $0,234 \mathrm{mg}$ seng/hari/ekor untuk mencit tua dalam konsentrasi $0,25 \mathrm{mg} / \mathrm{ml}$ sejak hari ke-0 sampai hari ke-10 setelah perlukaan. ${ }^{18}$

Hasil penelitian pada mencit tua dengan luka insisi didapatkan kadar MDA plasma lebih rendah dengan pemberian seng, namun analisis statistik dengan uji $\mathrm{T}$ tidak berpasangan tidak bermakna $(p=0,064)$. Hal ini dapat terjadi karena seng belum cukup lama diberikan untuk mendapatkan efek dalam menurunkan kadar MDA plasma pada penuaan.

Bao B dkk (2010) menunjukkan bahwa pemberian seng selama 6 bulan dapat menurunkan kadar C-reactive protein (CRP), interleukin-6 (IL-6), macrophage chemoattractant protein 1 (MCP-1), vascular cell adhesion molecule 1 (VCAM-1), secretory phospholopase A2, serta malondialdehid dan hidroksialkenal pada subjek lansia. Begitu pula Prasad AS dkk (2007) pada lansia berusia 55-87 tahun menemukan bahwa pemberian seng glukonat (45 mg seng elemental secara oral) selama 12 bulan dapat menurunkan kejadian infeksi, pembentukan tumour necrosing factor- $\alpha$ (TNF- $\alpha)$ dan penanda stres oksidatif plasma secara nyata pada kelompok yang diberi seng dibandingkan dengan placebo. ${ }^{22}$

Pemberian seng jangka panjang dapat menginduksi metallothionein pada berbagai organ seperti hati, ginjal dan usus. Metallothionein menunjukkan efek antioksidan pada berbagai kondisi, diantaranya paparan radiasi, toksisitas dari obat antikanker, toksisitas etanol dan mutagenesis. Pada kondisi stres oksidatif tinggi, perubahan pada status redoks seluler menyebabkan pelepasan seng dari metallothionein sebagai hasil perpindahan sulfida/disulfida. Szuster-Ciesielkaa dkk (2000) menunjukkan bahwa aktifitas antioksidan metallothionein yang mengandung seng dapat mencegah apoptosis epitel melalui perlindungan sel terhadap radikal bebas dan toksin kuman.

Pada penuaan, aktifitas radikal bebas yang ditunjukkan dengan kadar MDA plasma lebih tinggi sehingga inflamasi berlebihan dibandingkan dengan usia muda. Hal ini dapat menyebabkan penyembuhan luka terganggu pada penuaan. Walaupun secara statistik tidak 
bermakna, kadar MDA plasma lebih rendah dengan pemberian seng pada mencit tua dengan luka insisi sehingga inflamasi berkurang dan penyembuhan luka diharapkan dapat lebih baik.

Menurut Prasad AS (2009), peran seng sebagai antioksidan dan antiinflamasi terjadi melalui berbagai jalur. Pertama, seng berperan sebagai inhibitor NADPH oxidase (enzim yang digunakan dalam respiratory burst) sehingga menurunkan produksi radikal bebas. Kedua, seng bersama-sama dengan cuprum menjadi kofaktor dalam pembentukan enzim $\mathrm{Cu} / \mathrm{Zn}$-superoxide dismutase (SOD) yang meregulasi kadar superoksida intraseluler. Ketiga, seng membentuk bagian logam pada protein metallothionein yang berperan sebagai antioksidan. Keempat, seng sebagai bagian dari zinc-finger protein dan kelima, seng melalui jalur sinyal PPAR dapat menghambat aktifasi NF-kB sehingga terjadi penurunan pembentukan sitokin inflamasi.

Peran seng dalam sistem imun adalah dengan menjadi bagian integral thymulin, yaitu hormon timus yang terlibat dalam maturasi dan diferensiasi sel T. Ekspresi gen IL-2 dan IFN- $\gamma$ (sitokin Th1) bergantung seng. Sitokin IL-2 terlibat dalam aktifasi NK dan sel T sitolitik. Sitokin IL-12 dihasilkan oleh makrofag-monosit yang terstimulasi dan bergantung seng. IFN- $\gamma$ dan IL-12 bersama-sama berperan dalam membunuh parasit, virus, dan bekteri oleh makrofagmonosit. Sitokin Th2 tidak terpengaruh oleh defisiensi seng kecuali produksi IL-10 yang meningkat pada orang tua dengan defisiensi seng. Sitokin IL-10 yang meningkat berpengaruh balik pada fungsi Th1 dan makrofag. Adanya defisiensi seng menyebabkan pergeseran fungsi Th1 ke Th2 dan fungsi imun yang diperantarai sel terganggu. Defisiensi seng juga menyebabkan stres dan aktifasi makrofag-monosit, sehingga pembentukan sitokin inflamasi IL$1 \beta$, IL-6, IL-8 dan TNF- $\alpha$ meningkat.

Hasil uji $\mathrm{T}$ tidak berpasangan pada mencit muda dengan luka insisi didapatkan kadar MDA plasma lebih tinggi secara bermakna dengan pemberian seng. Pada hari ke-5 ketika diperiksa kadar MDA plasma, fase inflamasi sudah selesai sehingga normalnya kadar MDA plasma sudah rendah. Kadar MDA plasma pada mencit muda dengan luka insisi yang lebih tinggi dengan pemberian seng menunjukkan adanya stres oksidatif. Menurut Dalle-Donne I (2006) tingginya stres oksidatif menunjukkan bahwa pertahanan antioksidan seluler tidak cukup untuk menghentikan secara lengkap pembentukan ROS karena kelebihan produksi ROS, kehilangan pertahanan antioksidan, atau keduanya. ${ }^{19}$

Menurut Nriagu J (2007), enzim antioksidan superoxide dismutase (SOD) sangat sensitif terhadap perubahan rasio cuprum-seng plasma. ${ }^{20}$ Menurut Osredkar J (2011), penurunan kadar SOD sebagai penanda status cuprum telah dilaporkan pada asupan seng yang cukup tinggi yaitu sekitar $60 \mathrm{mg} /$ hari selama lebih dari 10 minggu.singh KB (2012) pada tikus menunjukkan bahwa pemberian seng di atas dosis farmakologis menyebabkan kadar cuprum, magnesium dan 
mangan menurun secara bermakna pada hati dan ginjal, peroksidasi lipid meningkat dan berbagai enzim antioksidan menurun. ${ }^{20}$

Perubahan rasio cuprum-seng menyebabkan aktifitas enzim antioksidan yang mengandung cuprum dan seng seperti superoxide dismutase (SOD), cytochrome-C oxidase (CCO), catalase (CAT) dan glutathione peroxidase (GPx) menurun. Selain itu, aktifitas banyak enzim berubah akibat status magnesium dan mangan yang menurun. Penurunan aktifitas berbagai enzim antioksidan dapat menyebabkan kelebihan radikal bebas, meningkatkan peroksidasi lipid yang lebih lanjut merusak membran sel. ${ }^{20}$

Pada penelitian ini tidak dilakukan pemeriksaan status seng sebelum dilakukan pemberian seng, sehingga tidak diketahui apakah mencit mengalami defisiensi seng atau tidak setelah perlukaan. Pemberian seng tanpa defisiensi dapat menyebabkan kelebihan seng pada mencit muda.

Homeostasis seng intraseluler mengontrol kadar ketersediaan langsung seng, diregulasi oleh metallothionein dan zinc finger protein. Metallothionein menyimpan seng dalam regulasi gen ketika seng plasma meningkat atau melepaskan seng ketika seng plasma rendah atau seng diperlukan untuk bergabung ke protein seng lain. Zinc finger protein selain berperan sebagai struktur protein dan meregulasi ekspresi gen, juga menyediakan seng dalam tubuh melalui metallothionein. Zinc finger protein diaktifkan oleh metallothionein dengan menjadi donor atau aseptor protein. ${ }^{20}$

Baik kelebihan maupun defisiensi seng menyebabkan stres oksidatif yang kemudian meningkatkan inflamasi. Lalu proses inflamasi meningkatkan produksi ROS lebih lanjut. Kelebihan seng pada diet dapat menginduksi obesitas, diabetes, dislipidemia dan hipertensi pada hewan. Kelebihan seng dapat menginduksi defisiensi cuprum, magnesium, mangan, zat besi dan selenium akibat interaksi antagonis; sementara mineral ini dibutuhkan sebagai kofaktor untuk aktifitas katalitik yang optimal dan mekanisme pertahanan antioksidan yang efektif. ${ }^{20}$ Kelebihan seng mengganggu proses bergantung logam yang lain atau menghambat protein lain. Seng dalam bentuk zinc oxide partikel nano telah diteliti dapat menyebabkan kenaikan produksi ROS yang kemudian menimbulkan stres oksidatif, apoptosis, dan nekrosis. ${ }^{21}$

Hasil uji T tidak berpasangan pada mencit dengan luka insisi yang diberi seng didapatkan kadar MDA plasma mencit muda lebih tinggi secara bermakna dibandingkan dengan mencit tua. Hal ini disebabkan oleh kadar MDA plasma mencit tua dengan luka insisi lebih rendah dengan pemberian seng walaupun tidak bermakna dan kadar MDA plasma mencit muda dengan luka insisi lebih tinggi secara bermakna dengan pemberian seng. 
Pada dasarnya, status stres oksidasi dan inflamasi pada penuaan lebih tinggi dibandingkan dengan usia muda. Pada penuaan terjadi respiratory burst yaitu produksi ROS dari aktifitas sel fagosit yang lebih tinggi dibandingkan dengan usia muda. Fulop dkk (2004) pada kultur neutrofil menunjukkan bahwa produksi superoksida dengan stimulasi formyl methionyl leucyl peptide bakteri pada lansia meningkat setelah 48 jam dibandingkan dengan dewasa muda. Hal ini mungkin dikarenakan neutrofil tua kurang efisien dalam regulasi menghentikan respon terhadap stimulasi dibandingkan dengan neutrofil muda.Selain itu produksi ROS intraseluler oleh metabolisme oksidatif yang terjadi di tingkat mitokondria meningkat dengan bertambahnya usia. Aktifitas berbagai enzim antioksidan pada penuaan menurun dibandingkan dengan usia muda. $^{18}$

Respon inflamasi terhadap antigen asing yang berhubungan dengan fungsi neutrofil pada penuaan menurun, namun pada penuaan terjadi kenaikan produksi sitokin proinflamasi yang mempertahankan status inflamasi kronik (inflamm-aging). Penelitian in vitro pada sel mononuklear (monosit dan limfosit) darah perifer menunjukkan bahwa pada lansia dihasilkan kadar sitokin proinflamasi (IL-6, IL-1 $\beta$ dan TNF- $\alpha$ ) yang lebih tinggi dibandingkan dengan dewasa muda. Kenaikan kadar sitokin proinflamasi sering ditemukan di tingkat sirkulasi maupun dalam kemampuan produksi sel. ${ }^{21}$

Walaupun memiliki status stres oksidasi dan inflamasi yang lebih tinggi, ternyata kadar MDA plasma mencit tua lebih rendah daripada mencit muda pada mencit dengan luka insisi yang diberi seng. Hal ini dapat terjadi karena peran antioksidan dan antiinflamasi seng dapat menurunkan kadar MDA plasma pada mencit tua di satu pihak. Namun di pihak lain, efek kelebihan seng menaikkan kadar MDA plasma pada mencit muda.

Pada penuaan terjadi defisiensi seng subklinis karena asupan rendah seng, kondisi penyakit yang meningkatkan kehilangan seng, status fisiologis yang membutuhkan banyak seng dan menurunnya absorpsi seng. Efek defisiensi seng diperberat dengan berbagai stres fisik seperti luka. Homeostasis seng intraseluler berubah dan beberapa transporter seng mengalami kerusakan dengan bertambahnya usia. Walaupun metallothionein meningkat, tapi tidak mampu melepaskan seng yang cukup. Pemberian seng pada mencit tua dapat mengkoreksi defisiensi seng yang terjadi.

Kelebihan seng dapat menyebabkan gangguan mineral yang lain, yaitu menurunnya kadar cuprum, magnesium dan mangan. Enzim antioksidan seperti SOD sangat sensitif terhadap perubahan rasio cuprum-seng plasma. Penurunan aktifitas SOD dan berbagai enzim antioksidan yang dibentuk oleh mineral yang lain oleh karena pemberian seng dapat menyebabkan 
kelebihan radikal bebas. ${ }^{22}$ Hal ini ditandai dengan meningkatnya kadar MDA plasma pada mencit muda.

Hasil penelitian pada mencit tua dengan luka insisi didapatkan reepitelialisasi, fibroblas, dan angiogenesis lebih banyak serta sel inflamasi lebih sedikit dengan pemberian seng, namun analisis statistik dengan uji Fisher tidak bermakna $(p>0,05)$. Hal ini menunjukkan bahwa penyembuhan luka yang berubah pada penuaan tidak dapat membaik secara bermakna dengan pemberian seng. Penelitian Aschroft GS dkk pada tikus tua dengan luka insisi akut menunjukkan bahwa produksi fibronektin berkurang, reepitelialisasi terlambat, produksi dan komposisi komponen matriks ekstraseluler berubah. Mungkin diperlukan mencit yang lebih tua untuk dapat menunjukkan perbaikan penyembuhan luka dengan pemberian seng. ${ }^{23}$

Penelitian Nishio N dkk pada tikus dengan luka akut menunjukkan bahwa infiltrasi neutrofil sebagai respon inflamasi setelah luka berlangsung lambat dan tidak memuncak pada tikus usia menengah dan tua, namun sangat cepat pada tikus muda. Jumlah neutrofil yang diperlukan untuk penyembuhan luka tikus tua lebih banyak dibandingkan dengan tikus muda, mungkin akibat fungsi neutrofil yang berkurang. Selain itu, pertambahan usia menyebabkan respon imun adaptif dan pertambahan kolonisasi bakteri sehingga pasien lansia menunjukkan penutupan luka yang terlambat dan cenderung menjadi luka kronik. ${ }^{24}$

Penelitian Aschroft G menemukan bahwa kadar tissue inhibitor metalloproteinase (TIMP) berkurang pada pada subjek yang berusia lebih dari 60 tahun dibandingkan dengan yang berusia kurang dari 40 tahun. Gangguan keseimbangan antara kadar MMP dan TIMP menyebabkan remodeling yang gagal berulang dan penyembuhan terlambat pada penuaan. ${ }^{25}$ Kadar matrix metalloproteinase (MMP)-2 lebih tinggi pada kulit lansia dibandingkan dengan dewasa muda. Pada luka akut, kadar MMP-2 dan MMP-9 meningkat pada kulit lansia daripada dewasa muda. Perubahan sitokin luka pada lansia ini mirip dengan profil sitokin luka kronik pada dewasa muda. ${ }^{12}$

Penelitian Holt secara in vitro menemukan bahwa lansia (lebih dari 65 tahun) mengalami reepitelialisasi yang terlambat nyata dibandingkan dengan subjek yang lebih muda (di bawah 55 tahun). Adapun deposisi kolagen dan jumlah sel pada kedua luka tampak identik. Hal ini didukung oleh penelitian pada babi dengan luka akut yang menunjukkan bahwa reepitelisasi terlambat dengan meningkatnya usia. Penyebabnya adalah jumlah dan lama pelepasan growth factor yang berkurang ${ }^{25}$

Hasil penelitian pada mencit muda dengan luka insisi didapatkan reepitelialisasi, fibroblas, dan angiogenesis lebih banyak serta sel inflamasi lebih sedikit dengan pemberian seng, namun analisis statistik dengan uji Fisher tidak bermakna $(p>0,05)$. Seperti yang telah 
dibahas sebelumnya, pada penelitian ini tidak diketahui apakah mencit mengalami defisiensi seng atau tidak setelah perlukaan. Hallbook dkk pada penderita ulkus vena kaki kronik menunjukkan bahwa suplementasi seng meningkatkan penyembuhan luka pada pasien yang telah mengalami status defisiensi seng sebelumnya, namun tidak berefek pada pasien dengan kadar seng awal normal. ${ }^{26}$

Kadar seng yang tinggi dapat memperlambat penutupan luka dan mengganggu produksi sitokin karena menghambat besi, mangan, dan/atau cuprum. Penelitian pada manusia menunjukkan bahwa asupan seng $300 \mathrm{mg} /$ hari dapat menurunkan beberapa marker fungsi imun, termasuk respon kemotaksis dan aktifitas fagosit neutrofil. Lim dkk (2004) menemukan bahwa seng dosis tinggi memperlambat penyembuhan luka karena penurunan absorpsi cuprum yang berperan penting dalam cross-linking kolagen pada penyembuhan luka. ${ }^{27}$

Walaupun kadar MDA plasma yang menunjukkan aktifitas radikal bebas pada mencit muda dengan luka insisi lebih tinggi dengan pemberian seng, penyembuhan luka tidak berbeda bermakna. Hal ini menunjukkan bahwa radikal bebas dengan pemberian seng tidak sampai mengganggu penyembuhan luka pada mencit muda, ditunjukkan dengan inflamasi pada penyembuhan luka yang tidak berlebihan. Hal ini dapat terjadi karena kenaikan ROS belum lama berlangsung, selain batas normal kadar MDA plasma yang tidak diketahui dan banyak faktor selain radikal bebas yang mempengaruhi penyembuhan luka.

Seng berperan dalam mempercepat migrasi keratinosit, membantu pertahanan terhadap apoptosis epitel dengan perlindungan sel oleh aktifitas antioksidan dari sistein yang kaya metallothionein. Seng juga memodulasi ekspresi integrin yang penting pada fase proliferasi dengan mempengaruhi mobilitas seluler. Studi in vitro Tenaud I dkk (1999) pada kultur monolayer sel epitel yang sedang berproliferasi menunjukkan bahwa seng terutama menginduksi integrin $\alpha_{3}, \alpha_{6}$, dan $\alpha_{\mathrm{V}}$. Rangkaian studi yang sama menunjukkan bahwa seng meningkatkan fungsi integrin $\alpha_{3}, \alpha_{\mathrm{V}}$, dan $\beta_{1}{ }^{28}$

Hasil uji Fisher pada mencit dengan luka insisi yang diberi seng didapatkan reepitelialisasi, angiogenesis dan sel inflamasi tidak berbeda antara mencit tua dan muda $(p>0,05)$; sementara fibroblas mencit muda lebih banyak daripada mencit tua $(p=0,01)$. Baik mencit tua maupun muda mengalami perbaikan skor histopatologi penyembuhan luka dengan pemberian seng walaupun tidak bermakna. Sampai hari ke-10 saat diperiksa skor histopatologi tidak terdapat perbedaan penyembuhan luka yang bermakna antara mencit tua dan mencit muda, kecuali pada parameter fibroblas.

Fibroblas merupakan sel utama di daerah luka pada fase proliferasi. Fibroblas bertanggung jawab untuk sintesis, deposisi, dan remodeling matriks ekstraseluler yang berupa 


\section{Research Article}

protein fibronektin, hialuronan, kolagen, dan proteoglikan. Kemudian fibroblas dan sel endotel vaskuler berproliferasi untuk membentuk jaringan granulasi sebagai tanda penyembuhan luka.

Fibroblas mencit muda lebih banyak daripada mencit tua dapat disebabkan oleh persentase fibroblas senesen yang meningkat pada penuaan. Fibroblas senesen menunjukkan ketidakmampuan berproliferasi, motilitas yang menurun, waktu laten yang bertambah, dan responsifitas terhadap stimulasi growth factor yang menurun. Jumlah dan ukuran fibroblas berkurang dengan perubahan komposisi lipid. ${ }^{24}$

Kemampuan fibroblas menghasilkan protein matriks ekstraseluler dan komposisi molekulernya terganggu pada penuaan. Gangguan ini antara lain penurunan kepadatan serat kolagen dengan bundel yang lebih tegak, pengurangan dan disorganisasi kolagen tipe I, peningkatan kolagen tipe III, penurunan jumlah asam hialuronat, dan penurunan ekspresi gen elastin. Selain itu, fibronektin mengalami peningkatan laju sintesis dan perubahan fisik sehingga menurunkan daya rekat sel. Perubahan matriks ekstraseluler menyebabkan fase proliferasi dan remodeling terganggu serta penutupan luka terlambat. ${ }^{22}$

Setelah hari ke-10 ada dua kemungkinan yang terjadi. Pertama, skor histopatologi penyembuhan luka mencit muda lebih baik dibandingkan dengan mencit tua. Suatu penelitian melaporkan bahwa tensile strength tikus muda dan tua serupa pada minggu pertama setelah luka. Namun setelah 3-5 minggu perkembangan tensile strength tikus tua berhenti, sementara tensile strength tikus muda terus bertambah. Oleh karena itu, jaringan penyembuhan luka pada tikus tua lebih lemah secara nyata dari pada tikus muda. ${ }^{26}$

Kedua, skor histopatologi penyembuhan luka mencit muda lebih buruk dibandingkan dengan mencit tua oleh karena efek radikal bebas yang menyebabkan penyembuhan luka terganggu pada mencit muda. Musalmah M dkk (2002) pada tikus normal dan tikus diabetik yang sama-sama mendapat perlukaan menemukan bahwa tikus diabetik yang memiliki kadar MDA plasma pada hari ke-5 dan 10 yang lebih tinggi mengalami laju penutupan luka yang lebih lambat dibandingkan dengan tikus normal. ${ }^{29}$

Radikal bebas meningkatkan inflamasi melalui produksi sitokin proinflamasi dan kemokin, menstimulasi kemotaksis dan migrasi neutrofil dan makrofag, serta menginduksi ekspresi molekul adhesi pada kapiler. ${ }^{25}$ Efek seluler langsung radikal bebas antara lain mengganggu migrasi, proliferasi dan sintesis matriks ekstraseluler pada fibroblas dan keratinosit. Radikal bebas juga menyebabkan ketidakseimbangan protease dan antiprotease.Radikal bebas menyebabkan fibroblas senesen sehingga tidak mampu bereplikasi, resisten terhadap apoptosis, dan memproduksi berbagai protein seperti MMP dan sitokin proinflamasi. Keadaan ini lebih lanjut menimbulkan kerusakan jaringan. ${ }^{25}$ 


\section{Simpulan}

Kadar MDA plasma mencit tua dengan luka insisi tidak berbeda dengan pemberian seng. Akan tetapi, kadar MDA plasma mencit muda dengan luka insisi lebih tinggi dengan pemberian seng. Kadar MDA plasma mencit muda lebih tinggi dibandingkan dengan mencit tua pada mencit dengan luka insisi yang diberi seng.

Reepitelialisasi, sel inflamasi, fibroblas dan angiogenesis tidak berbeda dengan pemberian seng, baik pada mencit tua maupun muda dengan luka insisi. Reepitelialisasi, sel inflamasi dan angiogenesis tidak berbeda antara mencit tua dan muda pada mencit dengan luka insisi yang diberi seng; sementara fibroblas mencit muda lebih banyak dibandingkan dengan mencit tua.

\section{Daftar Pustaka}

1. Driscroll P. Wound prevalence and wound management. 2009. [cited 201330 July]; Available from: http://blog.mediligence.com

2. Harris CL dan Fraser C. Malnutrition in the institutionalized elderly: The effects on wound healing. Ost Wound Manage. 2004;50(10):54-63.

3. Minimas DA. Ageing and its influence on wound healing. Wounds UK. 2007;3(1):46-50.

4. Singer AJ dan Clark RAF. Cutaneous wound healing. N Engl J Med. 1999;341(10):738-46.

5. Diegelmann RF dan Evans MC. Wound healing: An overview of acute, fibrotic and delayed healing. Front biosci. 2004;9:283-9.

6. Stechmiller JK. Understanding the role of nutrition and wound healing. Nutr Clin Pract. 2010;25(1):61-8.

7. Guo S dan DiPietro LA. Factors affecting wound healing. J Dent Res. 2010;89(3):219-29.

8. Bradbury S. Wound healing: is oral zinc supplementation beneficial Wounds. 2006;2(1):54-61.

9. King JC dan Cousins RJ. Specific dietary components. In: Shils ME, Shike M, Ross AC, Caballero B, Cousins RJ, editor. Modern Nutrition in Health and Disease. 10th ed. Philadhelphia: Lippincott Williams \& Wilkins; 2006.

10. Brown KL dan Phillips TJ. Nutrition and wound healing. Clin Dermatol. 2010;28:432-9.

11. Brunicardi FC, Andersen DK, Billiar TR, Dunn DL, Hunter JG, dkk. Wound healing. Schwartz's principles of surgery. Philadelphia: The McGraw-Hill Companies; 2007.

12. Novo E dan Parola M. Redox mechanisms in hepatic chronic wound healing and fibrogenesis. Fibrogen Tissue Rep. 2008;1(5):1-58.

13. Valko M, Leibfritz D, Moncol J, Cronin MTD, Mazur M, et al. Free radical and antioxidants in normal physiological functions and human disease. Int J Biochem Cell Bio. 2007;39:44-84.

14. Komi-Kuramochi A, Kawano M, Oda Y, Asada M, Suzuki M, dkk. Expression of fibroblast growth factors and their receptors during full-thickness skin wound healing in young and aged mice. J Endocrinol. 2005; 186:27389.

15. Satari MH dan Wirakusumah FF. Konsistensi penelitian dalam bidang kesehatan. Bandung: PT Refika Aditama; 2010. p. 107.

16. Bales CW dan Ritchie CS. Nutrition needs and assessment: the elderly. In: Shils ME, Shike M, Ross AC, Caballero B, Cousins RJ, editor. Modern Nutrition in Health and Disease. 10th ed. Philadelphia: Lippincott Williams \& Wilkins; 2006.

17. Sallit J. Rationale for zinc supplementation in older adults with wounds. ALTC. 2012;20(1):39-41.

18. Binnebosel M, Grommes J, Koenen B, Junge K, Klink CD, dkk. Zinc deficiency impairs wound healing of anastomosis in rats. Int J Colorectal Dis. 2010; 25:251-7.

19. Prasad AS. Zinc: role in immunity, oxidative stress and chronic inflammation. Curr Opin Clin Nutr Metab Care. 2009;12:646-52.

20. Singh KB. Long term excessive zn supplementation induced oxidative stress in wistar rats fed on semisynthetic diet. Food and Nutrition Sci. 2012; 3: 724-31.

21. Shen C, James SA, de Jonge MD, Turney TW, Wright PFA, Feltis BN. Relating cytotoxicity, zinc ion, and reactive oxygen in $\mathrm{ZnO}$ nanoparticle-exposed human immune cells. Toxicol Sci. 2013;136(1):120-30. 


\section{Research Article}

22. Singh KB. Long term excessive zn supplementation induced oxidative stress in wistar rats fed on semisynthetic diet. Food and Nutrition Sci. 2012;(3):724-31.

23. Aschroft GS, Horan MA, Ferguson MWJ. Aging is associated with reduced deposition of specific extracellular matrix components, an upregulation of angiogenesis, and an altered inflammatory response in a murine incisional wound healing model. J Invest Dermatol. 1997;108:430-7.

24. Nishio N, Okawa Y, Sakurai H, Isobe K. Neutrophil depletion delays wound repair in aged mice. Age. 2008;30:11-9.

25. Crooks A. How does ageing affect the wound healing process? JWC. 2005;14(5):222-23.

26. Aschroft GS, Horan MA, Ferguson MWJ. The effects of ageing on cutaneous wound healing in mammals. $J$ Anat. 1995;187:1-26.

27. Lim Y. The role of nutrition during the early inflammatory stage of cutaneous wound healing: The Ohio State University; 2003. [Cited 201214 September]; Available from: https://etd.ohiolink.edu

28. Taylor ME. Wonder why? Nutritional support for soft tissue healing. J Prolotherapy. 2011;3(3)

29. Musalmah M, Fairuz AH, Gapor MT, Ngah WZW. Effect of vitamin E on plasma malondialdehyde, antioxidant enzyme levels and the rates of wound closures during wound healing in normal and diabetic rats. Asia Pacific J Clin Nutr. 2002;11:S448-51. 